\title{
Pengaruh pendekatan problem solving terhadap kemampuan representasi dan literasi matematis siswa
}

\author{
Muh. Fajaruddin Atsnan ${ }^{1}{ }^{*}$, Rahmita Yuliana Gazali ${ }^{1}$, Maisea Ledua Nareki ${ }^{2}$ \\ ${ }^{1}$ Prodi Pendidikan Matematika, Sekolah Tinggi Keguruan dan Ilmu Pendidikan PGRI Banjarmasin, Jl. \\ Sultan Adam Kompleks H. Iyus No 18, Banjarmasin 70121, Indonesia. \\ ${ }^{2}$ Head of Mathematics and Physics, Gospel High School, Dhanji Street, Samabula, Suva, Fiji. \\ * Corresponding Author. E-mail: ats_krnbangettt@yahoo.co.id \\ Received: 28 June 2018; Revised: 19 August 2018; Accepted: 31 August 2018
}

\begin{abstract}
Abstrak
Pada konteks penilaian berskala internasional seperti Programme for International Student Assessment (PISA), kompetensi pemecahan masalah dalam bidang matematika dan sains terkait permasalahan nyata merupakan fokus pengembangan kompetensi representasi dan literasi matematis siswa. Mengingat pentingnya pemecahan masalah, kemampuan representasi dan literasi matematis, maka penelitian ini bertujuan untuk mengetahui pengaruh pendekatan problem solving terhadap kemampuan representasi dan literasi matematis siswa SMP. Metode yang digunakan pada penelitian ini adalah metode eksperimen semu (quasi experimental), dengan desain penelitian yang digunakan adalah Randomized Posttest-Only Control Group Design, yakni dua kelas yang telah dipilih secara acak, selanjutnya diberikan perlakukan yang diakhiri dengan tes kemampuan representasi dan literasi matematis pada kedua kelas tersebut. Berdasarkan hasil kajian dan analisis data dapat disimpulkan bahwa pembelajaran matematika dengan pendekatan problem solving berpengaruh terhadap kemampuan representasi dan literasi matematis siswa SMP, khususnya di kelas VIII SMP Negeri 7 Banjarmasin. Terlihat jelas perbedaan cara menyelesaikan masalah yang diujikan kepada siswa kelas eksperimen dan kelas kontrol. Melalui pendekatan problem solving, terbukti dapat menjadikan siswa terbiasa ketika menjumpai soal-soal pemecahan masalah setingkat soal PISA atau TIMSS.
\end{abstract}

Kata Kunci: problem solving, representasi matematis, literasi matematis

\section{The effect of problem solving approach toward students' mathematical representation and literacy skill}

\begin{abstract}
In the context of international scale assessment such as Programme for International Student Assessment (PISA), problem-solving competence in the field of mathematics and science related to real problems was the focus of developing students' mathematical representation and literacy competence. Given the importance ability of problem solving, mathematical representation and literacy, this study aimed to determine the effect of problem solving approach toward the ability of mathematical representation and literacy of junior high school students. The method used in this research was quasi experimental method, with the research design used was Randomized Posttest-Only Control Group Design, i.e. two classes that have been chosen randomly, then given treatment which ends with the test of mathematical representation and literacy in both classes. Based on the results of study and data analysis, it could be concluded that mathematics learning with problem solving approach affects the ability of mathematical representation and literacy of junior high school students, especially in class VIII SMP Negeri 7 Banjarmasin, Indonesia. There was a clear difference in how students solve the problems tested between the experiment class and control class. Through the problem solving approach, it was proven to make the students accustomed when encountering problem solving problems which similarity with PISA or TIMSS problems.
\end{abstract}

Keywords: problem solving, mathematical representation, mathematical literacy

How to Cite: Atsnan, M., Gazali, R., \& Nareki, M. (2018). Pengaruh pendekatan problem solving terhadap kemampuan representasi dan literasi matematis siswa. Jurnal Riset Pendidikan Matematika, 5(2), 135-146. doi:https://doi.org/10.21831/jrpm.v5i2.20120

Permalink/DOI: https://doi.org/10.21831/jrpm.v5i2.20120 
Jurnal Riset Pendidikan Matematika, 5 (2), 2018 - 136

Muh. Fajaruddin Atsnan, Rahmita Yuliana Gazali, Maisea Ledua Nareki

\section{PENDAHULUAN}

Dalam konteks penilaian berskala internasional seperti PISA, kompetensi pemecahan masalah dalam bidang matematika dan sains terkait permasalahan nyata merupakan fokus pengembangan kompetensi representasi dan literasi matematis siswa (Jonassen, 2011; Kind, 2013; Kuo, Hull, Gupta, \& Elny, 2013; Organisation for Economic Co-operation and Development, 2005). Oleh sebab itu, guru matematika seharusnya sudah mengenalkan pemecahan masalah matematika dari yang umum, kemudian membiasakan untuk menghadirkan masalah dunia nyata yang menuntut siswa menggunakan stra-tegi pemeecahan masalah, ketika siswa mengenyam pendidikan di sekolah dasar dan menengah (Greiff, Holt, \& Funke, 2013; Wu \& Adams, 2006). Bahkan NCTM menganjurkan bahwa tujuan pembelajaran matematika di sekolah, seyogyanya juga menekankan pada pentingnya pemecahan masalah (problem solving) di setiap pembelajaran matematika. Artinya bahwa, pemecahan masalah bukan hanya sekadar tujuan pembelajaran matematika di sekolah, tetapi sudah menjadi fokus utama di setiap pembelajarna matematika.

Namun, permasalahan yang muncul kemudian, yang masih terjadi di Indonesia adalah baik guru matematika maupun siswanya, belum membiasakan diri dengan pemecahan masalah matematika. Sehingga, kontribusi konsep-konsep matematika yang sudah dipelajari, terhadap pemecahkan masalah, terutama di PISA belum maksimal, yang dibuktikan dengan hasil tes, yang menempatkan Indonesia berada di bawah ratarata hasil PISA standarnya OECD (Thien, Darmawan, \& Ong, 2015). Padahal, di Indonesia, mata pelajaran matematika diwajibkan di setiap jenjang pendidikan formal, mulai dari Sekolah Dasar, Sekolah Menengah Pertama (SMP), dan Sekolah Menengah Atas (SMA). Di mana, setiap jenjang memiliki tingkat kesulitan yang berbedabeda dengan karakteristik materi yang berbeda, mulai dari perhitungan sederhana sampai yang kompleks. Apalagi di setiap kompetensi dasar di sekolah menengah pertama, selalu mengikutkan kata dalam pemecahan masalah (Menteri Pendidikan Nasional Republik Indonesia, 2006). Namun, sampai saat ini pembelajaran yang terjadi masih sebatas belajar menyelesaikan soal dengan rumus, belum menyelesaikan masalah nyata dengan strategi pemecahan masalah.

Tujuan dalam setiap pembelajaran matematika adalah untuk mengembangkan kemampu- an dan keterampilan siswa dalam berpikir matematis. Kemampuan berpikir matematis tidak sekadar menyampaikan berbagai materi seperti aturan/rumus/dalil, definisi, serta prosedur, yang seolah-olah menggiring siswa untuk lihai dalam menghafal, tetapi bagaimana menstimulus siswa untuk aktif mengkontruksi pengetahuan dengan mengaitkan pengalaman pengetahuan sebelumnya, dengan yang baru diperoleh. Untuk berpikir secara matematis, siswa harus dapat mengemukakan dua hal. Pertama, bisa menyampaikan ideide matematikanya dalam berbagai cara, yang kemudian disebut dengan kemampuan representasi matematis. NCTM, menyebutkan bahwa dalam belajar matematika, siswa diharapkan memiliki kemampuan pemahaman, pemecahan masalah, koneksi matematis, dan merepresentasikan ide-ide matematisnya. Kemampuan representasi matematis dapat memperkaya pengetahuan matematis siswa karena bisa digunakan untuk menyelesaikan masalah sehari-hari. Representasi yang memenuhi persyaratan tertentu seperti kompleksitas, keterkaitan dan kekuatan simbolisasi dan abstraksi akan memperluas dan memperkaya kecerdasan manusia, terutama dalam pemodelan dalam pemecahan masalah di kehidupan nyata (Villegas, Castro-Martínez, \& Gutiérrez-Pérez, 2009). Kedua, bisa memilih dan menerapkan strategi pemecahan masalah sederhana, menginterpretasikan dan menggunakan representasi berdasarkan sumber informasi dan mengemukakan alasan, serta mengembangkan komunikasi tertulis sederhana melalui hasil analisis, interpretasi, dan penalaran (Organisation for Economic Co-operation and Development, 2014).

Salah satu solusi yang ditawarkan untuk menyelesaikan masalah yang terjadi adalah dengan mengenalkan kepada siswa, sedini mungkin tentang pemecahan masalah matematika, memperkenalkan konsep matematika dalam bingkai pemecahan masalah (Scherer \& Beckmann, 2014). Berdasarkan uraian permasalahan tersebut, maka penelitian ini bertujuan untuk mengetahui pengaruh pendekatan problem solving terhadap kemampuan representasi dan literasi matematis siswa SMP Kelas VIII.

\section{METODE}

Metode yang digunakan pada penelitian ini adalah metode eksperimen semu (quasi experimental), karena tidak dapat sepenuhnya mengontrol faktor-faktor eksternal (luar) yang mempengaruhi kemampuan representasi dan literasi matematis siswa (Sugiyono, 2010, p. 77). 
Kemudian, akan diuji pengaruh pendekatan problem solving yang diterapkan dalam pembelajaran di kelas eksperimen (kelas VIII E) dan pembelajaran langsung (konvensional) yang diterapkan pada kelas kontrol (kelas VIII D), untuk membandingkan kemampuan representasi dan literasi matematis siswa.

Desain penelitian yang digunakan pada penelitian ini adalah Randomized Posttest-Only Control Group Design, yakni dua kelas yang telah dipilih secara acak, selanjutnya diberikan perlakukan yang diakhiri dengan tes kemampuan representasi dan literasi matematis pada kedua kelas tersebut. Desain penelitian tersebut tersaji pada Tabel 1.

Tabel 1. Rancangan Desain Penelitian

\begin{tabular}{ccc}
\hline Kelas & Perlakuan & Post-Test \\
\hline KE & XE & O \\
KK & - & O \\
\hline
\end{tabular}

Keterangan:

KE: Kelas Eksperimen

KK: Kelas Kontrol

XE: Perlakukan di kelas eksperimen (kelas VIII E), yaitu pendekatan problem solving

O: Tes kemampuan representasi dan literasi matematis untuk kedua kelas (Sukmadinata, 2013, p. 206).

Sebelum melakukan tes, maka di kelas eksperimen diterapkan pembelajaran matematika dengan pendekatan problem solving, sedangkan untuk kelas kontrol dengan pendekatan konvensional. Selanjutnya, akan dilihat pengaruh perlakuan khusus di kelas eksperimen dilihat dari variabel terikatnya yakni kemampuan representasi dan literasi matematis siswa. Populasi pada penelitian ini adalah seluruh siswa kelas VIII SMP Negeri 7 Banjarmasin di semester genap tahun ajaran 2017-2018. Teknik pengambilan sampel adalah dengan cluster random sampling, dimana kelas terpilih pada pengocokan pertama sebagai eksperimen (kelas VIII E) dan kelas yang terpilih kedua sebagai kelas kontrol (VIII D).

Instrumen penelitian ini berupa soal-soal uraian yang diberikan dalam bentuk posttest. Instrument diberikan ke kelas eksperimen dan kelas kontrol pada pokok bahasan Statistika, untuk mengukur kemampuan representasi dan literasi matematis siswa. Kompetensi Dasar (KD) pada penelitian ini adalah menganalisis data berdasarkan distribusi data, nilai rata-rata, median, modus, dan sebaran data untuk mengambil kesimpulan, membuat keputusan, atau membuat prediksi. Adapun indikator representasi matematis yang diukur dalam penelitian ini tersaji pada Tabel 2 sedangkan untuk indikator literasi matematis yang diukur pada penelitian ini tersaji pada Tabel 3.

Tabel 2. Indikator Representasi Matematis

\begin{tabular}{|c|c|}
\hline $\begin{array}{c}\text { Indikator } \\
\text { Representasi }\end{array}$ & Indikator Operasional \\
\hline Visual & $\begin{array}{l}\text { Menyajikan kembali data atau informasi dari suatu masalah kehidupan sehari-hari dalam } \\
\text { bentuk tabel dan diagram batang atau diagram lingkaran }\end{array}$ \\
\hline $\begin{array}{l}\text { Ekspresi/Persamaan } \\
\text { Matematis }\end{array}$ & $\begin{array}{l}\text { Menentukan nilai rata-rata (mean), median, dan modus dari suatu masalah di kehidupan } \\
\text { sehari-hari }\end{array}$ \\
\hline $\begin{array}{l}\text { Kata-kata atau teks } \\
\text { tertulis }\end{array}$ & $\begin{array}{l}\text { Menuliskan jawaban atas suatu masalah kehidupan sehari-hari yang berkaitan dengan } \\
\text { distribusi data statistik dalam bentuk kata-kata atau teks tertulis, dengan terlebih dahulu } \\
\text { menganalisis data. }\end{array}$ \\
\hline
\end{tabular}

Tabel 3. Indikator Literasi Matematis

\begin{tabular}{|c|c|c|c|}
\hline Level & Indikator Literasi & Indikator Operasional & Konten PISA \\
\hline 3 & $\begin{array}{l}\text { Menginterpretasikan dan menggunakan } \\
\text { representasi berdasarkan sumber } \\
\text { informasi dan mengemukakan alasan } \\
\text { Mengembangkan komunikasi tertulis } \\
\text { sederhana melalui hasil analisis, } \\
\text { interpretasi, dan penalaran }\end{array}$ & $\begin{array}{l}\text { Melaksanakan analisis data, membuat prediksi, } \\
\text { atau membuat keputusan berdasarkan suatu } \\
\text { masalah yang disajikan dalam bentuk diagram. } \\
\text { Memahami masalah, merencanakan } \\
\text { penyelesaian, melaksanakan rencana } \\
\text { penyelesaian, serta melihat kembali proses dan } \\
\text { hasil dari suatu data yang disajikan. } \\
\text { Menginterpretasikan nilai rata-rata (mean), } \\
\text { median, dan modus berdasarkan data yang } \\
\text { disajikan dalam bentuk tabel. } \\
\text { Mengembangkan komunikasi tertulis } \\
\text { sederhana melalui hasil analisis, interpretasi, } \\
\text { dan penalaran, tentang mean, modus, dan } \\
\text { median dari suatu masalah yang diberikan. }\end{array}$ & $\begin{array}{l}\text { Peluang dan } \\
\text { Penyajian } \\
\text { Data }\end{array}$ \\
\hline
\end{tabular}


Jurnal Riset Pendidikan Matematika, 5 (2), 2018 - 138

Muh. Fajaruddin Atsnan, Rahmita Yuliana Gazali, Maisea Ledua Nareki

Kriteria penskoran terhadap jawaban siswa untuk tiap butir soal tes kemampuan representasi matematis siswa, dimodifikasi dari Cai, Lane, dan Jakabscin (1996), sedangkan penskoran terhadap jawaban siswa untuk tiap butir soal tes kemampuan literasi matematis siswa, dimodifikasi dari penskoran PISA. Sebelum digunakan, instrumen penelitian tersebut divalidasi terlebih dahulu diujicobakan agar diketahui reliabilitasnya. Validasi dilakukan melalui expert judgement dan estimasi reliabilitas menggunakan Alpha Cronbach (Arikunto, 2013, p. 109). Hasil validasi oleh ahli menunjukkan bahwa untuk tes kemampuan representasi matematis, ketiga butir soal valid, sedangkan untuk tes kemampuan literasi matematis, keempat butir soal valid. Hasil estimasi reliabilitas dengan Alpha Cronbach menunjukkan bahwa untuk tes kemampuan representasi matematis diperoleh koefisien $\mathbf{r}_{11}=$ 0.783 , sehingga berada pada kategori baik, sedangkan untuk tes kemampuan literasi matematis diperoleh koefisien $r_{11}=0,633$, dan berada pada kategori baik.

Teknik analisis data dengan analisis kuantitatif, untuk membandingkan hasil tes kelas eksperimen dan kelas kontrol, yaitu dengan uji perbedaan dua rata-rata untuk sampel bebas (independen), yang didahului oleh uji normalitas dan uji homogenitas sebagai syarat analisis data.

\section{HASIL DAN PEMBAHASAN}

Sebelum diberikan tes kemampuan representasi matematis dan literasi matematis, siswa kelas eksperimen yaitu kelas VIII E SMP Negeri 7 Banjarmasin melaksanakan pembelajaran matematika pada materi statistika dengan menerapkan pendekatan problem solving. Guru merancang Rencana Pelaksanaan Pembelajaran (RPP) untuk pembelajaran (1) penyajian data statistik beserta analisisnya; (2) mean, median, modus beserta analisisnya. Pada kegiatan inti pembelajaran, guru menggunakan Lembar Kerja Siswa yang didalamnya terdapat kegiatan-kegiatan yang disusun berdasarkan tahapan penyelesaian masalah dari G. Polya yang dimodifikasi yaitu memahami masalah (understand), merencanakan penyelesaian dan melaksanakan rencana penyelesaian (plan \& carry out), serta memeriksa kembali hasil dan proses (look back). Sedangkan untuk siswa kelas kontrol di kelas VIII D SMP Negeri 7 Banjarmasin, tetap menerapkan pembelajaran langsung dengan pendekatan konvensional.

Pada tahap pertama pendekatan problem solving yaitu memahami masalah (understand), siswa diajak untuk dapat menuliskan seluruh informasi yang terdapat pada masalah yang diberikan, yang mana informasi tersebut akan digunakan untuk menyelesaikan masalah yang diberikan. Kemudian, pada tahap kedua, yaitu merencanakan penyelesaian (plan), siswa diajak untuk membiasakan diri merancang penyelesaian masalah, berdasarkan informasi atau data-data yang sudah dituliskan di tahap pertama. Guru memposisikan diri sebagai fasilitator, menstimulus siswa untuk dapat merancang rencana penyelesaian (solusi) dari permasalahan yang diberikan. Pada tahap ini, setelah siswa menuliskan rencana penyelesaian, mereka diberikan kesempatan untuk berdiskusi untuk menuliskan penyelesaian sesuai dengan rencana awal (carry out).

Tahap selanjutnya, adalah memeriksa kembali penyelesaian yang sudah dituliskan (look back). Pada tahap ini siswa diajak untuk kembali mengecek penyelesaian yang sudah dituliskan dari awal hingga akhir (proses), serta hasil penyelesaian (hasil), apakah sudah tepat atau belum. Pada tahap ini, guru juga memberikan kesempatan kepada siswa, untuk menuliskan penyelesaian alternatif (cara lain untuk menyelesaikan masalah) serta memberikan penguatan dan penegasan akan penyelesaian yang sudah dituliskan siswa.

Pembelajaran matematika dengan pendekatan problem solving di kelas eksperimen pada materi statistika dilaksanakan dengan menggunakan Lembar Kerja Siswa (LKS). LKS yang disusun berdasarkan langkah-langkah pendekatan problem solving, pada materi penyajian data statistik dan menghitung rata-rata hitung (mean), modus, serta median. Untuk langkah understand, plan, dan carry out, rata-rata siswa menuliskan jawaban. Sedangkan untuk tahap looking back, tidak ada satu kelompok pun yang menuliskan jawaban, tetapi mereka akan menjawab tidak ada cara penyelesaian lain, karena jawaban penyelesaian mereka yakni sudah benar.

Gambar 1 merupakan LKS beserta hasil penyelesaian di satu kelompok. Hasil kerja salah satu kelompok, pada langkah memahami masalah (understand), tampak pada Gambar 2. 
Jurnal Riset Pendidikan Matematika, 5 (2), 2018 - 139

Muh. Fajaruddin Atsnan, Rahmita Yuliana Gazali, Maisea Ledua Nareki

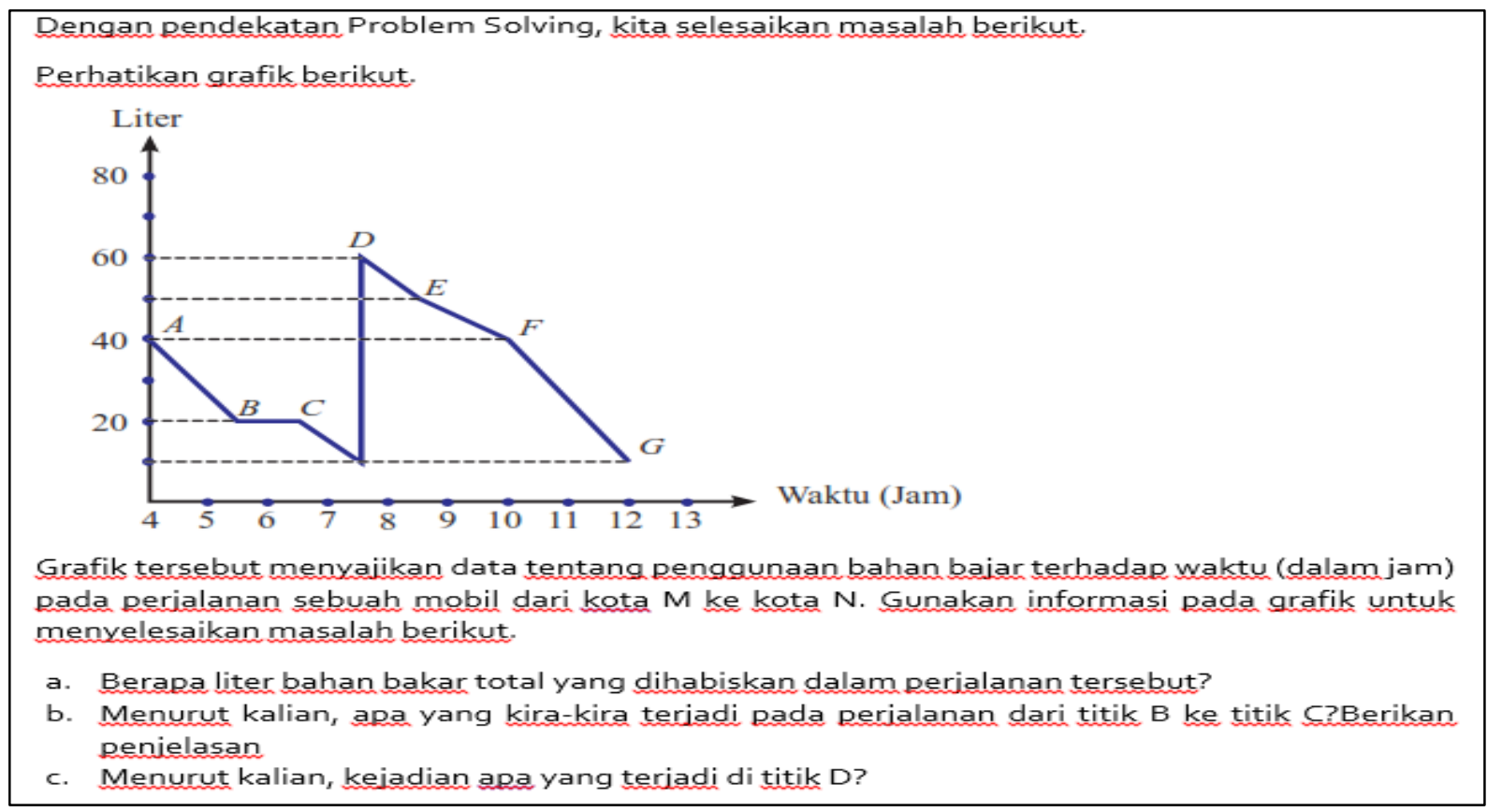

Gambar 1. Masalah pada LKS 1

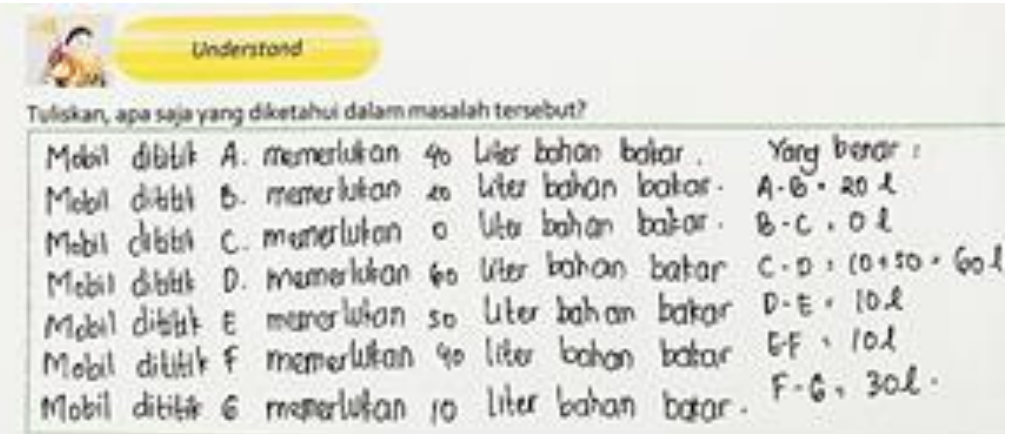

Gambar 2. Pekerjaan Siswa pada Langkah Understand

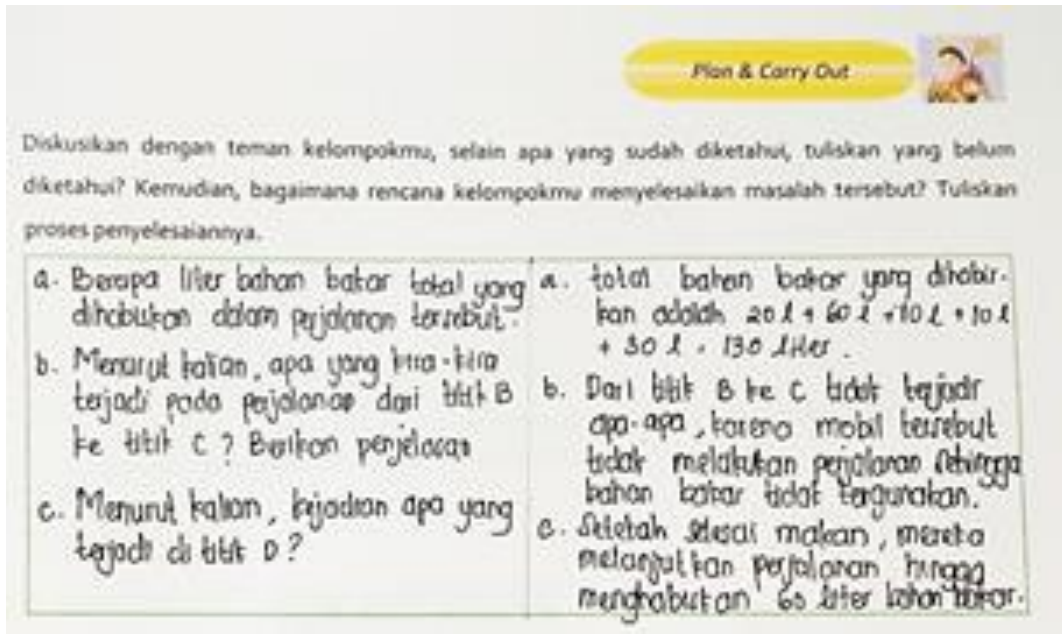

Gambar 3. Pekerjaan Siswa pada Langkah Plan \& Carry Out

Berdasarkan Gambar 2, tampak bahwa siswa sudah menuliskan data/informasi yang diketahui atau tertera pada soal. Untuk dapat menuliskan informasi yang diketahui pada soal, siswa terlebih dahulu harus memahami bagai- mana membaca data dalam bentuk grafik. Setelah menuliskan data/informasi yang diperlukan untuk menyelesaikan masalah, maka siswa kemudian menuliskan rencana (plan) dan menyelesaikan masalah sesuai rencana (carry 
out). Masih di kelompok yang sama, hasil kerja pada langkah kedua dan ketiga pada pendekatan problem solving, tampak pada Gambar 3.

Berdasarkan Gambar 3 tersebut, nampak bahwa yang dimaksud dengan rencana penyelesaian oleh kelompok itu adalah menuliskan kembali pertanyaan yang ada pada soal. Untuk mempermudah menyelesaikannya. Sedangkan untuk hasil perhitungan (coret-coret) ada pada kertas lain. Pada Gambar 3, juga nampak bahwa siswa menyelesaikan (carry out) dalam bentuk uraian kata, menuliskan langkah penyelesaian secara runtut, tidak langsung pada jawaban akhir.

Sedangkan untuk langkah keempat, yaitu memeriksa kembali proses dan hasil kerja, tidak dilakukan oleh kelompok tersebut. Ketika ditanya, mereka menunjukkan hasil kerja diskusi berbentuk coret-coret hasil hitungan di kertas lain, dan tidak menuliskan di tempat looking back.

Selanjutnya, setelah siswa kelas eksperimen melaksanakan pembelajaran dengan pendekatan problem solving, dan siswa kelas kontrol tetap dengan pembelajaran langsung atau konvensionalnya, mereka melaksanakan tes kemampuan representasi dan literasi matematis. Berikut ini akan dideskripsikan hasil tes kemampuan representasi dan literasi matematis siswa.

\section{Kemampuan Representasi Matematis Siswa}

Perbandingan kemampuan representasi matematis siswa antara kelas eksperimen yang pembelajarannya menerapkan pendekatan problem solving dan kelas kontrol yang pembelajarannya menerapkan pendekatan konvensional berdasarkan indikator, terlihat pada Tabel 4. Jika dilihat dari tiga indikator tes kemampuan representasi matematis, maka siswa kelas eksperimen memiliki kemampuan representasi matematis lebih baik dibandingkan dengan kemampuan representasi matematis siswa di kelas kontrol. Meskipun dari tiga indikator soal tes, siswa kelas eksperimen masih lemah ketika harus menuliskan persamaan atau ekspresi matematis dalam bentuk simbol, hanya dua siswa yang memiliki skor hampir ideal untuk indikator persamaan matematis/ekspersi matematis. Selebihnya, bisa menjawab benar, tetapi tidak bisa menuliskannya dalam bentuk persamaan yang benar. Sedangkan di kelas kontrol, ada dua indikator dengan persentase siswa yang berhasil menjawab benar di bawah 50\% yaitu indikator menuliskan penyelesaian dalam bentuk persamaan/ekspresi matematis dan menuliskan penyelesaian dalam bentuk kata-kata.

Berdasarkan tiga soal yang diujikan pada tes kemampuan representasi matematis, untuk soal nomor 1 untuk mengukur kemampuan representasi bentuk visual, rata-rata siswa kelas eksperimen bisa menyajikan kembali data dalam bentuk diagram batang, setelah sebelumnya melengkapi informasi yang sudah ada, dengan mencari informasi tambahan untuk menyempurnakan hasil.

Tabel 4. Perbandingan Kemampuan Representasi Matematis Siswa

\begin{tabular}{clcccccc}
\hline \multirow{2}{*}{ No. } & \multirow{2}{*}{ Indikator } & \multicolumn{3}{c}{ Eksperimen } & \multicolumn{3}{c}{ Kontrol } \\
\cline { 3 - 8 } & & Skor Ideal & Mean & Tuntas (\%) & Skor Ideal & Mean & Tuntas (\%) \\
\hline 1. & Visual & 4 & 2,84 & 70,96 & 4 & 2,19 & 54,84 \\
2. & Ekspresi/persamaan matematis & 12 & 4,06 & 33,87 & 12 & 3,03 & 25,27 \\
3. & Kata-kata/teks tertulis & 4 & 2,19 & 54,84 & 4 & 1,74 & 43,55 \\
\hline
\end{tabular}

Tabel 5. Perbandingan Kemampuan Literasi Matematis Siswa

\begin{tabular}{clrrrrrr}
\hline \multirow{2}{*}{ No. } & \multicolumn{1}{c}{ Indikator } & \multicolumn{3}{c}{ Eksperimen } & \multicolumn{3}{c}{ Kontrol } \\
\cline { 3 - 8 } & $\begin{array}{r}\text { Skor } \\
\text { Ideal }\end{array}$ & Mean & $\begin{array}{c}\text { Tuntas } \\
(\%)\end{array}$ & $\begin{array}{c}\text { Skor } \\
\text { Ideal }\end{array}$ & Mean & $\begin{array}{c}\text { Tuntas } \\
(\%)\end{array}$ \\
\hline 1. & $\begin{array}{l}\text { Melaksanakan prosedur dengan baik, termasuk } \\
\text { prosedur yang memerlukan keputusan secara } \\
\text { berurutan }\end{array}$ & 4 & 2,7 & 67,7 & & 0,5 & 12,1 \\
2. & $\begin{array}{l}\text { Memilih dan menerapkan strategi pemecahan } \\
\text { masalah sederhana }\end{array}$ & 4 & 2,1 & 52,4 & 4 & 0,4 & 11,3 \\
3. $\begin{array}{l}\text { Menginterpretasikan dan menggunakan } \\
\text { representasi berdasarkan sumber informasi dan } \\
\text { mengemukakan alasan }\end{array}$ & 8 & 4,9 & 60,9 & 8 & 0,6 & 6,9 \\
4. & $\begin{array}{l}\text { Mengembangkan komunikasi tertulis sederhana } \\
\text { melalui hasil analisis, interpretasi, dan penalaran }\end{array}$ & 4 & 2,2 & 55,7 & 4 & 0,3 & 7,3 \\
\hline
\end{tabular}


Jurnal Riset Pendidikan Matematika, 5 (2), 2018 - 141

Muh. Fajaruddin Atsnan, Rahmita Yuliana Gazali, Maisea Ledua Nareki

Demikian juga untuk soal nomor 3 untuk mengukur kemampuan representasi bentuk katakata atau teks tertulis. Meskipun tidak sebanyak siswa yang dapat menyelesaikan permasalahan pada butir soal nomor 1, tetapi lebih dari jumlah 50\% siswa di kelas eksperimen mampu menuliskan secara benar penyelesaian dari soal yang berhubungan dengan distribusi data statistik. Kurangnya kemampuan representasi matematis di kelas eksperimen, tampak dari butir soal nomor 2 untuk mengukur indikator ekspresi/persamaan matematis, dimana kurang dari setengah banyak siswa yang mampu menyelesaikannya.

Berdasarkan analisis jawaban, kebanyakan siswa kelas eksperimen sudah bisa menjawab dengan benar bagaimana menentukan mean, median, dan modus, tetapi tidak cermat dalam menuliskan simbol mean, median, dan modus. Dengan kata lain, pembelajaran matematika dengan pendekatan problem solving dengan empat tahap yang dilaksanakan, yaitu memahami masalah, merencanakan penyelesaian, melaksanakan rencana, dan memeriksa hasil serta proses, mampu diterima dengan baik oleh siswa di kelas eksperimen, dengan bukti mampu mengaplikasikan kebiasaan menyelesaikan masalah saat pembelajaran pada tes kemampuan representasi matematis.

\section{Kemampuan Literasi Matematis Siswa}

Perbandingan kemampuan literasi matematis siswa antara kelas eksperimen yang pembelajarannya menerapkan pendekatan problem solving dan kelas kontrol yang pembelajarannya menerapkan pendekatan konvensional berdasarkan indikator, terlihat pada Tabel 5.

Berdasarkan hasil tes kemampuan literasi matematis siswa, lebih dari setengah jumlah siswa di kelas eksperimen, mampu menyelesaikan empat soal yang diujikan, meskipun masih banyak siswa yang tidak mampu menyelesaikan soal dikarenakan tidak cukup waktu. Kebiasaan menyelesaikan masalah dengan langkah-langkah pendekatan problem solving pada saat pembelajaran, khususnya saat diskusi tentang lembar kegiatan siswa, mampu diterapkan sebagian besar siswa di kelas eksperimen pada saat menyelesaikan masalah-masalah yang ada di tes kemampuan literasi matematis. Sedangkan untuk siswa di kelas kontrol, masih perlu pembiasaan menyelesaikan masalah matematika dengan langkah-langkah yang benar, karena jika melihat hasil tes, menunjukkan kurang dari 50\% dari jumlah siswa di kelas kontrol yang mampu menyelesaikan tes kemampuan representasi matematis, bahkan ada yang tidak mampu menjawab untuk beberapa butir soal, sehingga skor 0 .

\section{Uji Hipotesis untuk Kemampuan Representasi Matematis}

Sebelum dilakukan uji hipotesis untuk mengetahui ada tidaknya perbedaan kemampuan representasi matematis siswa kelas eksperimen dan kelas kontrol, maka dilakukan uji prasyarat yaitu uji normalitas dan homogenitas data. Uji prasyarat dilakukan dengan bantuan SPSS 24, yang hasilnya tampak pada Tabel 6 .

Tabel 6. Hasil Uji Normalitas Data Representasi Matematis

\begin{tabular}{lr|r|r|r|r|r}
\hline & \multicolumn{3}{c}{$\begin{array}{c}\text { Kolmogorov- } \\
\text { Smirnova }\end{array}$} & \multicolumn{3}{c}{ Shapiro-Wilk } \\
& Statistic & Df & Sig. & Statistic & Df & Sig. \\
\hline Eksperimen & .265 & 31 & .000 & .818 & 31 & .000 \\
\hline Kontrol & .200 & 31 & .003 & .770 & 31 & .000 \\
\hline
\end{tabular}

Berdasarkan hasil tersebut, tampak bahwa responden $\leq 50$, sehingga digunakan ShapiroWilk, yaitu $p$-value/sig $0,000 \leq 5 \%$, maka data hasil tes kemampuan representasi matematis tidak berdistribusi normal. Sedangkan untuk uji homogenitas melalui uji Lavene, dengan bantuan SPSS 24, hasilnya tampak pada Tabel 7.

Tabel 7. Hasil Uji Homogenitas pada Variabel Representasi Matematis

\begin{tabular}{rr|r|r|r}
\hline Levene Statistic & \multicolumn{1}{c|}{ df1 } & \multicolumn{1}{c}{ df2 } & \multicolumn{1}{c}{ Sig. } \\
\hline .468 & 3 & 25 & .707 \\
\hline
\end{tabular}

Karena, $p$-value $=0,707>5 \%$, artinya data berasal dari sampel yang homogen. Berdasarkan hasil uji prasyarat, yang menunjukkan bahwa data hasil tes kemampuan representasi matematis tidak berdistribusi normal, maka selanjutnya dilanjutkan uji hipotesis, dengan statistik non parametrik, berbantukan SPSS 24, yang hasilnya tampak pada Tabel 8.

Tabel 8. Hasil Uji Hipotesis Perbedaan

Kemampuan Representasi Matematis

\begin{tabular}{lr}
\hline & \multicolumn{1}{c}{ Nilai } \\
\hline Mann-Whitney U & 23.500 \\
\hline Wilcoxon W & 519.500 \\
\hline Z & -6.482 \\
\hline Asymp. Sig. (2-tailed) & .000 \\
\hline
\end{tabular}

Hasil analisis data dengan bantuan SPSS 24 menunjukkan bahwa nilai sig $0,000 \leq 5 \%$, sehingga $\mathrm{H}_{0}$ ditolak dan $\mathrm{H}_{1}$ diterima. Jadi, hasil penelitian menunjukkan bahwa terdapat perbedaan signifikan kemampuan representasi matematis siswa pada kelas eksperimen dan kelas kontrol. 
Jurnal Riset Pendidikan Matematika, 5 (2), 2018 - 142

Muh. Fajaruddin Atsnan, Rahmita Yuliana Gazali, Maisea Ledua Nareki

Dengan kata lain ada pengaruh signifikan pendekatan problem solving terhadap kemampuan representasi matematis siswa.

\section{Uji Hipotesis untuk Kemampuan Literasi Matematis}

Sebelum dilakukan uji hipotesis untuk mengetahui ada tidaknya perbedaan kemampuan literasi matematis siswa kelas eksperimen dan kelas kontrol, maka dilakukan uji prasyarat yaitu uji normalitas dan homogenitas data. Uji prasyarat dilakukan dengan bantuan SPSS 24, yang hasilnya tampak pada Tabel 9.

Tabel 9. Hasil Uji Normalitas Data Literasi Matematis

\begin{tabular}{|c|c|c|c|c|c|c|}
\hline & \multicolumn{3}{|c|}{$\begin{array}{l}\text { Kolmogorov- } \\
\text { Smirnov }^{\mathrm{a}}\end{array}$} & \multicolumn{3}{|c|}{ Shapiro-Wilk } \\
\hline & Statistic & $\mathrm{df}$ & Sig. & Statistic & $\mathrm{Df}$ & Sig \\
\hline & .252 & 31 & .000 & .844 & 31 & .000 \\
\hline Kontrol & .409 & 31 & .000 & .599 & 31 & .000 \\
\hline
\end{tabular}

Berdasarkan hasil tersebut, tampak bahwa responden $\leq 50$, sehingga digunakan ShapiroWilk, yaitu $\mathrm{p} /$ sig $0,000 \leq 5 \%$, maka data hasil tes kemampuan literasi matematis tidak berdistribusi normal. Sedangkan untuk uji homogenitas melalui uji Lavene, dengan bantuan SPSS 24, hasilnya tampak pada Tabel 10.

Tabel 10. Hasil Uji Homogenitas pada Variabel Litearsi Matematis

\begin{tabular}{r|r|r|c}
\hline \multicolumn{1}{c|}{ Levene Statistic } & df1 & \multicolumn{1}{c}{ df2 } & Sig. \\
\hline 1.875 & 3 & 24 & .161 \\
\hline
\end{tabular}

Karena, $\mathrm{p}$-value $=0,161>5 \%$, artinya data berasal dari sampel yang homogen. Berdasarkan hasil uji prasyarat, yang menunjukkan bahwa data hasil tes kemampuan literasi matematis tidak berdistribusi normal, maka selanjutnya dilanjutkan uji hipotesis, dengan statistik non parametrik, berbantukan SPSS 24, yang hasilnya tampak pada Tabel 11.

Tabel 11. Hasil Uji Hipotesis Perbedaan Kemampuan Literasi Matematis

\begin{tabular}{lr}
\hline & \multicolumn{1}{c}{ Nilai } \\
\hline Mann-Whitney U & 40.000 \\
\hline Wilcoxon W & 536.000 \\
\hline Z & -6.366 \\
\hline Asymp. Sig. (2-tailed) & .000 \\
\hline
\end{tabular}

Hasil analisis data dengan bantuan SPSS 24 menunjukkan bahwa nilai sig $0,000 \leq 5 \%$, sehingga $\mathrm{H}_{0}$ ditolak dan $\mathrm{H}_{1}$ diterima. Jadi, hasil penelitian menunjukkan bahwa terdapat perbedaan signifikan kemampuan literasi matematis siswa pada kelas eksperimen dan kelas kontrol. Dengan kata lain ada pengaruh signifikan pendekatan problem solving terhadap kemampuan literasi matematis siswa.

Mengacu pada hasil penelitian yang menunjukkan bahwa melalui pembelajaran matematika dengan pendekatan problem solving, berpengaruh terhadap kemampuan representasi dan literasi matematis, maka hendaknya para guru matematika mulai membiasakan diri untuk mengenalkan pendekatan pembelajaran berbasis pemecahan masalah. Maupun strategi, model, metode pembelajaran yang mampu menjadikan matematika sebagai suatu kegiatan dan aktivitas insani di setiap pembelajaran matematika. Melalui pendekatan problem solving, terbukti dapat menjadikan siswa terbiasa ketika menjumpai soal-soal pemecahan masalah selevel PISA atau TIMSS.

\section{Pembahasan}

Berdasarkan hasil uji hipotesis, dikatakan bahwa pendekatan problem solving berpengaruh terhadap kemampuan representasi dan literasi matematis siswa. Artinya bahwa pembelajaran matematika dengan pendekatan problem solving lebih efektif dalam membangun representasi siswa yang mencakup: (1) representasi visual (diagram, tabel, atau grafik), (2) pemodelan/ persamaan/ekspresi matematis, serta (3) menuliskan dalam bentuk kata-kata atau teks tertulis. Maupun kemampuan literasi matematis yang mencakup: (1) melaksanakan prosedur yang memerlukan keputusan secara berurutan dan sistematis, (2) memilih dan menerapkan strategi pemecahan masalah sederhana, (3) menginterpretasikan dan mengemukakan alasan secara logis, serta (3) mengembangkan komunikasi tertulis sederhana melalui hasil analisis, interpretasi dan penalaran. Dengan kata lain, secara tidak langsung, langkah-langkah pada pendekatan problem solving mampu mengembangkan pemikiran siswa untuk kemudian belajar mandiri dan terbiasa menyelesaikan soal secara bertahap (Ersoy, 2016, p. 79).

Pendekatan problem solving merupakan salah satu pendekatan pembelajaran yang dapat diterapkan dalam pembelajaran matematika, dimana siswa distimulus untuk lebih aktif dalam membangun pengetahuan tentang konsep-konsep matematika. Guru sebatas fasilitator serta memberikan bantuan (scaffolding) ketika siswa mengalami kesulitan setelah terlebih dahulu berfikir untuk bagaimana memahami masalah, merencanakan penyelesaian, melaksanakan penyelesaian, 
Jurnal Riset Pendidikan Matematika, 5 (2), 2018 - 143

Muh. Fajaruddin Atsnan, Rahmita Yuliana Gazali, Maisea Ledua Nareki

serta memeriksa kembali penyelesaian yang sudah disusun. Meskipun pada saat awal pembelajaran, siswa merasa kesulitan ketika diminta menyelesaikan masalah yang ada pada LKS yang berbasis pendekatan problem solving. Hal ini terjadi karena mereka belum terbiasa mengerjakan LKS dengan langkah-langkah yang sistematis dan urut. Situasi ini terjadi karena masih seringnya pembelajaran langsung, konvensional, sehingga siswa hanya berperan sebagai pendengar dan pencatat materi yang secara keseluruhan disampaikan oleh guru. Hal ini bisa berdampak pada siswa kurang berani dalam mengemukakan ide atau gagasan atau pendapat, serta pertanyaan ketika ada konsep matematika yang belum dipahami (Rahmawati, 2015, pp. 63-64).

Namun, mulai pertemuan kedua, siswa berangsur-angsur terbiasa dengan pendekatan pembelajaran problem solving, sehingga lebih antusias mengikuti pembelajaran, baik pada saat berdiskusi, sering bertanya, hingga berani memaparkan hasil kerja atau diskusi, untuk dipresentasikan di depan kelas.

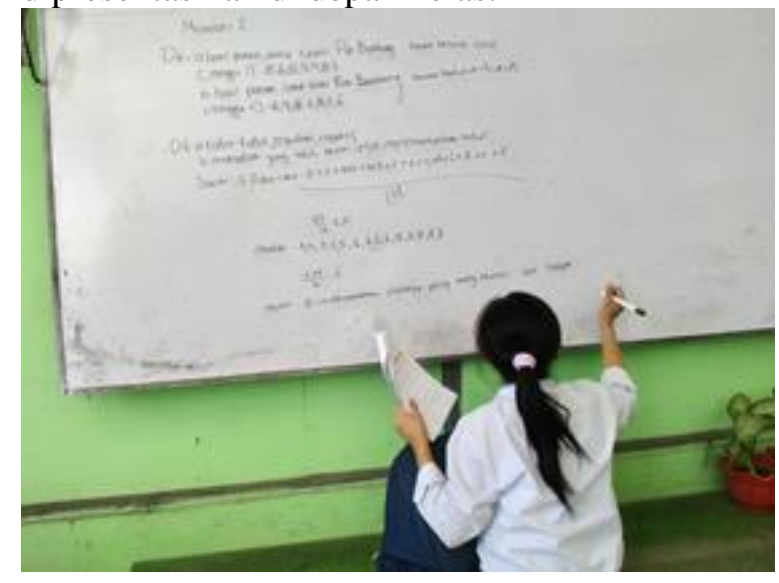

Gambar 4. Siswa Menuliskan Hasil Diskusi di Papan Tulis

Membangun Kemampuan Representasi

Dalam pembelajaran matematika melalui problem solving yang tergambar pada LKS, mampu membangun kemampuan representasi siswa. Pada langkah memahami masalah (understand), siswa diharapkan mampu untuk mengumpulkan data atau informasi yang terdapat pada soal/masalah yang selanjutnya akan digunakan sebagai dasar menyelesaikan masalah tersebut. Kemudian, pada langkah kedua, merencanakan penyelesaian (plan), siswa diharapkan mampu menenetukan cara untuk menyelesaikan masalah yang benar secara internal, bisa melalui coret-coret di lain kertas. Selanjutnya, pada langkah ketiga, menyelesaikan masalah (carry out), siswa diharapkan mampu menuliskan bagaimana mereka menyelesaikan masalah, memindah jawaban di lembar bantu (coret-coret) ke tempat yang sudah disediakan. Langkah terakhir, memeriksa kembali proses dan hasil (looking back), siswa diharapkan mampu memeriksa langkah demi langkah sampai diperoleh hasil penyelesaian masalah.

Langkah-langkah yang ada pada pendekatan problem solving, mampu membantu siswa untuk membiasakan diri berpikir logis, Sistematis, dan analisis. Hal ini penting untuk membangun konsep dan prosedur matematika siswa, yang salah satunya bisa diajarkan melalui penyelesaian masalah (Van de Walle, 2010, p. 37). Namun, yang menjadi catatan pada penelitian ini adalah semua siswa di kelas eksperimen tidak menuliskan penyelesaian dengan cara yang berbeda pada langkah keempat, looking back pada saat mengerjakan LKS. Semua siswa terpaku pada satu jawaban/penyelesaian yang sudah dianggap benar, tanpa mau menyelesaikan dengan cara atau strategi yang berbeda. Padahal langkah-langkah penyelesaian masalah berkontribusi pada pengembangan pemahaman konsep matematika siswa, sehingga siswa mampu untuk menggunakan strategi, solusi yang berbeda (Ersoy, 2016, p. 86). kondisi seperti ini berdampak pada hasil tes kemampuan representasi siswa, yang hanya menuliskan satu cara atau strategi menyelesaikan soal. Berikut ini, sampel hasil tes kemampuan representasi siswa untuk soal nomor 1 dan 2, yang berbunyi:

\section{Soal nomor 1}

Perhatikan diagram lingkaran berikut.

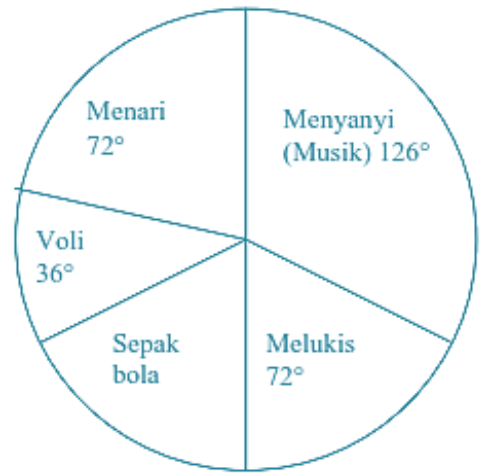

Gambar 5. Diagram Hobi Siswa

Gambar 5 Diagram lingkaran tersebut menggambarkan hobi (kegemaran) siswa di suatu sekolah. Jika banyak siswa yang hobi menyanyi (musik) ada 14 orang, tentukan:

a. Selisih antara banyak siswa keseluruhan dengan banyak siswa yang hobi Sepakbola. 
Jurnal Riset Pendidikan Matematika, 5 (2), 2018 - 144

Muh. Fajaruddin Atsnan, Rahmita Yuliana Gazali, Maisea Ledua Nareki

b. Buatlah diagram batang untuk menggambarkan hobi keseluruhan siswa di suatu sekolah tersebut.

\section{Soal nomor 2}

\section{Perhatikan diagram batang berikut.}

Ribuan Liter

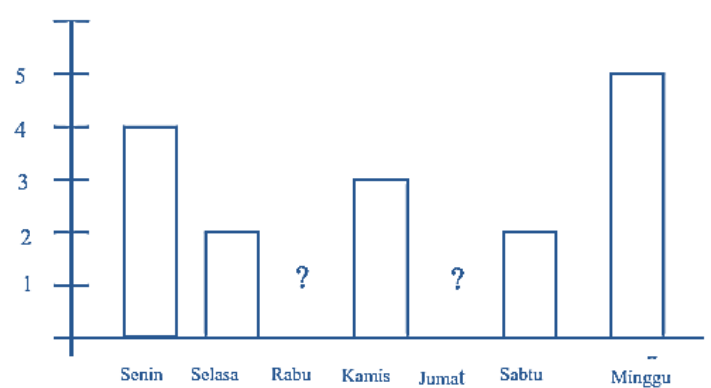

Gambar 6. Diagram Penjualan Bensin dalam Satu Minggu

Diagram tersebut menunjukkan penjualan bensin dalam 1 minggu. Namun, data hasil penjualan hari Rabu dan Jumat terhapus. Hasil penjualan bensin di hari Rabu sama dengan dua kali hasil penjualan bensin di hari Jumat. Jika rata-rata penjualan bensin dalam 1 minggu adalah 4.000 liter, maka tentukan jumlah penjualan bensin di hari Rabu dan Jumat.

Gambar 7 merupakan hasil pekerjaan salah seorang siswa untuk soal nomor 1 dan 2. Dari Gambar 7 tampak bahwa siswa tersebut sudah mampu untuk membangun representasi matematis baik visual maupun berbentuk persamaan matematis. Namun, cukup menuliskan satu penyelesaian yang dianggap benar. Hal ini terjadi karena belum terbiasanya siswa untuk memikirkan, merencanakan dan melaksanakan penyelesaian dengan strategi, pola maupun cara berbeda.

Membangun Kemampuan Literasi Matematis

Pendekatan problem solving memang sangat penting untuk membangun aspek matematika yaitu kemampuan literasi matematis, melalui pembelajaran (Liljedahl, Santos-Trigo, Malaspina, \& Bruder, 2016, p. 1). Namun demikian, hasil tes kemampuan literasi matematis siswa berbeda dengan kemampuan representasi matematisnya, dimana banyak siswa di kelas eksperimen belum benar untuk menjawabnya.

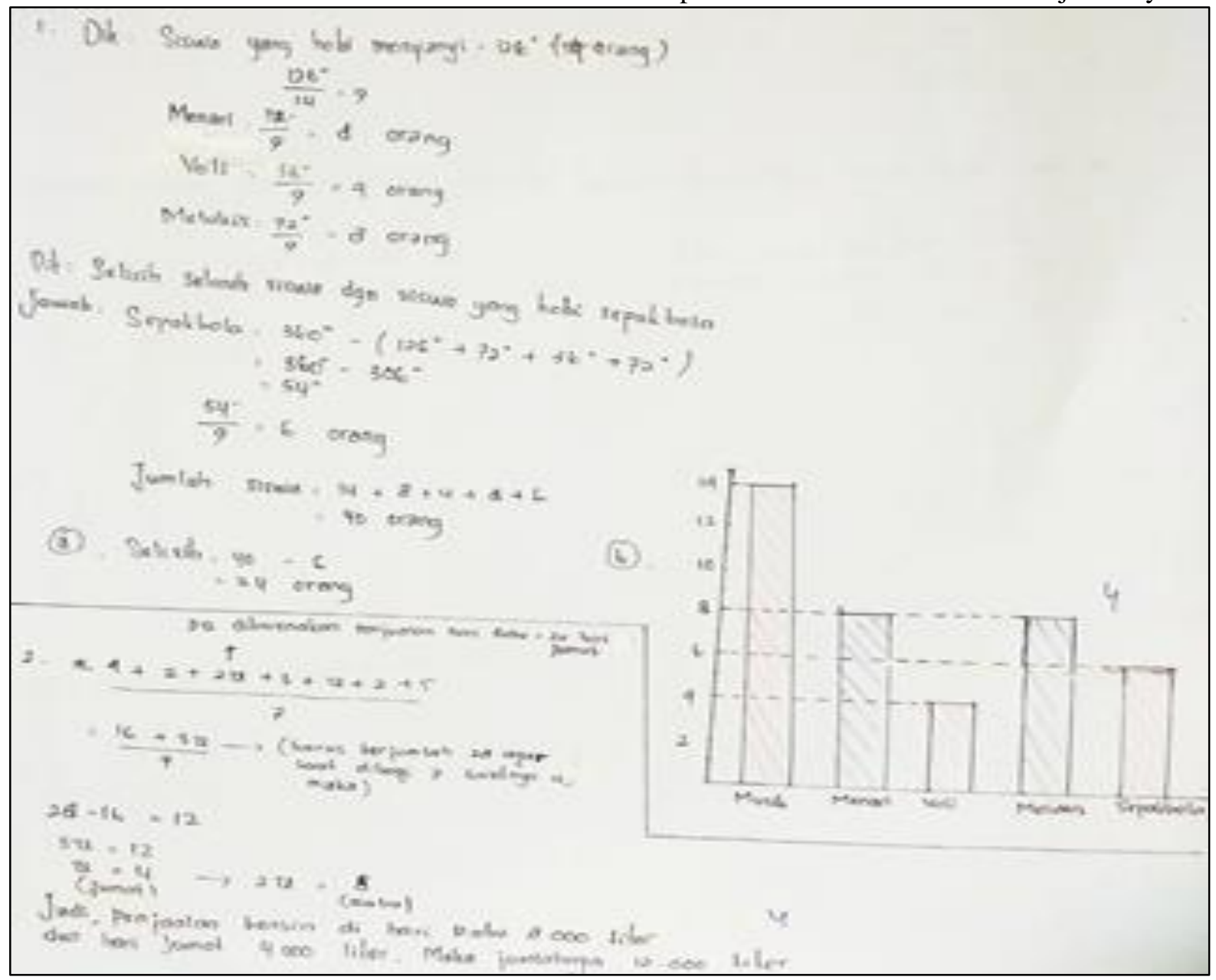

Gambar 7. Sampel hasil Tes Kemampuan Representasi 
Meskipun demikian, hasil tes kemampuan literasi matematis siswa kelas eksperimen jauh lebih baik dibandingkan dengan siswa kelas kontrol, menunjukkan perlu pembiasaan pembelajaran yang mengarah pada berpikir tingkat tinggi, seperti analisis, sintetis, dan mencipta. Pekerjaan rumah bagi para pendidik saat ini adalah ketika kita lagi gencar membangun budaya literasi, termasuk literasi matematis, maka perlu pembiasaan secara kontinyu, berkelanjutan, dan terus-menerus, yang dikemas secara sistematis melalui pendekatan problem solving atau pemecahan masalah (Ersoy, 2016, p. 86). Harapannya, melalui pembiasaan di setiap pembelajaran matematika sejak dini, dapat meningkatan keterampilan siswa, khususnya dalam membangun kemampuan literasi matematis, yang dalam penelitian ini hanya dibatasi pada soal-soal yang setara dengan PISA level 3.

\section{SIMPULAN}

Berdasarkan hasil kajian dan analisis data, maka dapat disimpulkan bahwa pembelajaran matematika dengan pendekatan problem solving berpengaruh terhadap kemampuan representasi dan literasi matematis siswa SMP, khususnya di kelas VIII SMP Negeri 7 Banjarmasin. Hal ini terlihat dari perbedaan cara menyelesaikan masalah yang diujikan kepada siswa kelas eksperimen dan kelas kontrol. Siswa di kelas eksperimen yang sudah terbiasa menyelesaikan masalah dengan langkah-langkah pendekatan problem solving, terlihat biasa dalam menyelesaikan soal tes.

Kelemahan hasil penelitian ini yaitu untuk langkah looking back, semua siswa tidak menuliskan jawabannya, padahal pada langkah itulah siswa menjadi lebih terasah kemampuan representasi dan literasi matematisnya. Namun demikian, pendekatan problem solving lebih efektif diterapkan pada pembelajaran matematika untuk meningkatkan kemampuan representasi maupun literasi matematis siswa. Dengan demikian pendekatan problem solving dapat dijadikan sebagai salah satu alternatif bagi guru untuk melatihkan kemampuan representasi dan literasi siswa pada materi-materi lainnya. Cakupan wilayah penelitian memang sangat sempit, tetapi memberikan gambaran kepada peneliti, maupun guru matematika, agar membiasakan diri dengan penyelesaian masalah sesuai yang sudah dianjurkan oleh pemerintah. Untuk itu disarankan agar kedepannya dilakukan penelitian dengan topik yang sama dengan menggunakan populasi yang lebih luas, sehingga memungkinkan generalisasi yang lebih luas terkait dampak pendekatan problem solving dalam meningkatkan prestasi belajar matematika siswa.

\section{DAFTAR PUSTAKA}

Arikunto, S. (2013). Dasar-dasar evaluasi pendidikan. Jakarta: Bumi Aksara.

Ersoy, E. (2016). Problem solving and its teaching in mathematics. The Online Journal of New Horizons in Education, 6(2), 79.

Greiff, S., Holt, D. V., \& Funke, J. (2013). Perspectives on problem solving in educational assessment: Analytical, interactive, and collaborative problem solving. The Journal of Problem Solving, 5(2). $\quad$ https://doi.org/10.7771/19326246.1153

Jonassen, D. H. (2011). Learning to solve problems: An instructional design guide. John Wiley \& Sons.

Kind, P. M. (2013). Establishing assessment scales using a novel disciplinary rationale for scientific reasoning. Journal of Research in Science Teaching, 50(5), 530560. https://doi.org/10.1002/tea.21086

Kuo, E., Hull, M. M., Gupta, A., \& Elny, A. (2013). How students blend conceptual and formal mathematical reasoning in solving physics problems. Science Education, $\quad$ 97(1), 32-57. https://doi.org/10.1002/sce.21043

Liljedahl, P., Santos-Trigo, M., Malaspina, U., \& Bruder, R. (2016). Problem solving in mathematics education. Springer, Cham. https://doi.org/10.1007/978-3-319-407302_1

Menteri Pendidikan Nasional Republik Indonesia. Peraturan Menteri Pendidikan Nasional Republik Indonesia Nomor 22 Tahun 2006 tentang standar isi untuk satuan pendidikan dasar dan menengah, Pub. L. No. 22, Peraturan Menteri (2006). Indonesia.

Organisation for Economic Co-operation and Development. (2005). PISA 2003 technical report. Paris: Organisation for Economic Co-operation and Development.

Organisation for Economic Co-operation and Development. (2014). PISA 2012 results: Creative problem solving: Students' skills in tackling real-life problems (Volume V). OECD, Paris, France. 
Jurnal Riset Pendidikan Matematika, 5 (2), 2018 - 146

Muh. Fajaruddin Atsnan, Rahmita Yuliana Gazali, Maisea Ledua Nareki

Rahmawati, P. S. (2015). Pengaruh pendekatan problem solving terhadap kemampuan representasi matematis siswa. UIN Syarif Hidayatullah.

Scherer, R., \& Beckmann, J. F. (2014). The acquisition of problem solving competence: evidence from 41 countries that math and science education matters. Large-Scale Assessments in Education, 2(1), 10. https://doi.org/10.1186/s40536014-0010-7

Sugiyono. (2010). Metode penelitian kuantitatif kualitatif dan $R \& D$. Bandung: Alfabeta.

Sukmadinata, N. S. (2013). Metode penelitian pendidikan. Bandung: PT Remaja Rosdakarya.

Thien, L. M., Darmawan, I. G. N., \& Ong, M. Y. (2015). Affective characteristics and mathematics performance in Indonesia, Malaysia, and Thailand: what can PISA 2012 data tell us? Large-Scale Assessments in Education, 3(1), 3. https://doi.org/10.1186/s40536-015-0013$\mathrm{Z}$

Van de Walle, J. A. (2010). Elementary and middle school mathematics: teaching developmentally. Boston: Pearson /Allyn and Bacon.

Villegas, J. L., Castro-Martínez, E., \& GutiérrezPérez, J. (2009). Representations in problem solving: a case study with optimization problems. Electronic Journal of Research in Educational Psychology, 7(1), 279-308 . Retrieved from http://www.investigacionpsicopedagogica.org/revista/new/english/ ContadorArticulo.php?297

Wu, M., \& Adams, R. (2006). Modelling mathematics problem solving item responses using a multidimensional IRT model. Mathematics Education Research Journal, $18(2)$, 93-113. https://doi.org/10.1007/BF03217438 